Vol. 1, No. 1, 2020

\title{
PATIENCE THERAPY TO REDUCE ADOLESCENTS' ANXIETY ASSESSED FROM PERSONALITY AND PARENTING
}

\author{
${ }^{1 *}$ Risydah Fadilah, ${ }^{2}$ Abd. Madjid \\ ${ }^{12}$ Universitas Muhammadiyah Yogyakarta, Indonesia \\ 1*risydah@staff.uma.ac.id; 2abdulmadjid@umy.ac.id
}

\section{ARTICLE INFO}

\section{Article History}

Received 11/1/2020

Revised 9/3/2020

Accepted 10/4/2020

\section{Keywords}

Patience

Personality

Parenting

Anxiety in Adolescents

Patience Therapy

\begin{abstract}
Student's character or personality is inseparable from the parenting process at home and the influence of the social environment. The research method used was Quasi-Experimental. The results of data processing were obtained for anxiety, namely for the experimental group, the value of $Z=-1,362^{a}$ with $p=0,173$ since $p 0.173>0.05$. This result means that there was a decrease in anxiety symptoms that were not so significant after being given a pretest and posttest in the experimental group. For the control group, the value of $Z=-0.440^{\mathrm{a}}$ was with $p=0.660$ since $p 0.660>0.05$. This result means that there was a decrease in anxiety symptoms that were not so significant before (pretest) and after (posttest) in the control group. The results of data processing obtained results for patience, that was for the experimental group, the value of $Z=-2.666^{a}$ with $p=0.008$ since $p$ $0.008<0.05$, then $\mathrm{H} 0$ was rejected, and H1 was accepted. This result means that there was a significant increase in patience after a pretest and posttest in the experimental group. For the control group, the value of $Z=-1.629^{a}$ was with $p=0.103$ since $p 0.103>0.05$, H0 was accepted, and $\mathrm{H} 1$ was rejected. This result means that there was no significant increase in patience before (pretest) and after (posttest) in the control group
\end{abstract}

This is an open access article under the CC-BY-SA license.

\section{INTRODUCTION}

Education is a conscious effort to grow and develop the potential of human resources or students by encouraging and facilitating their learning activities as in Law number 20 of 2003 concerning the National Education System Chapter 1 Article 1. Education is a conscious and planned effort to create an atmosphere of learning and learning process. So that students actively develop their potential to have spiritual strength, self-control, personality (Setiawan, 2018), intelligence, noble character, and the skills needed by themselves, the nation, and state-society.

Al-Abrasy (1970), in the discourse of Islamic education, defines education as an effort to prepare individuals to live a perfect life. Sheikh Musthafa al-Ghulayani 
(spirit) reveals that education is the cultivation of noble morals into the souls of children who are growing and pouring it with instructions and advice so that it becomes inherent, in the form of virtue and kindness, like charity for the benefit of the nation.

The purpose of education is to create one's quality and character so that he has a broad view of the future to achieve the desired goals and can adapt quickly and precisely in various environments (Chaer et al., 2019). There will be educational objectives achievement if conducted with proper teaching and learning processes both in the school environment. In the educational process, in addition to the program or learning methods, some students play an essential role in the process of receiving lessons. In Indonesia, students include the levels of elementary school, junior high school, and high school with varying age levels.

Generally, junior high school students have an age of around 12-16 years. According to Santrock (2002), this age belongs to adolescence, the period of development of the transition from childhood to early adulthood. Based on data from the Central Statistics Agency (BPS) of North Sumatra, the number of adolescents aged 15-24 years is $2,514,109$ people. While the number of adolescents in Indonesia reaches is around 65 million people or 25 percent of the 258 million people in Indonesia. With this large number and proportion, the knowledge, views, ways of thinking, attitudes, and decisions of adolescents are influential, not only for the youth group itself but for the entire population and especially families which not only affect the future but also in the present, i.e., at the junior high school level.

Adolescence is a period of transition from childhood to adulthood, where there are several developmental tasks to pass (Hurlock, 2000). The task of these developments, such as physical, psychological, social, and moral changes. Most teenagers are not ready to face developmental tasks that occur so that it will cause various problems. In general, adolescents spend more time with peers than parents and get a source of affection, sympathy, understanding, and moral guidance from their peers (Papalia \& Feldman, 2009).

The character of the interaction in the family begins to change in adolescence period. Teenagers experience pressure between their dependence on parents and the need to become independent individuals. Parents also often have mixed feelings within themselves. They want their children to become independent, but they realize that it is not the time yet to let their children become independent (Chaer, 2020). Parents always want the best for their children, and one of the desires of the parents, for example, is excellent academic achievement such as good grades and high-class ranking through some rules and discipline in learning. However, such expectations can exert excessive pressure and burden on children and especially how these expectations are through parenting. 


\section{A. Parenting Style}

Parenting style, according to Spera (2005), is an emotional climate where parents raise their children. Parenting styles are behavioural patterns used by primary caregivers to interact with their children. These parenting patterns then create an emotional atmosphere expressed by the behaviour of their parents. There are several parenting styles done by parents to their children, according to Baumrind (in Dehyadegary et al., 2011). They are authoritative, who is demanding and responsive, authoritarian, who is demanding but not responsive, and permissive, who is responsive but not demanding. Dobre et al. (2014) add that each type of parenting has different effects on the child's mental appreciation that can cause anxiety and emotions (Nikoogoftar \& Seghatoleslam, 2015).

Pressure and burden in the form of hopes and desires from parents can shape the character and personality of children. Still (Konstantinos, 2019), if parents provide stimuli in the form of expectations that are beyond the abilities of children and in an aggressive way, there is a possibility that children will only feel pressured and burdened by the expectations. It will only make the child tries hard to please his parents and avoid punishment. The child may lose the fundamental essence of learning and why learning is essential and done. Moreover, extra stresses and burdens can cause children to experience various kinds of psychological stress, such as learning fatigue, anger at their parents, and other problems at school or home environment, creating their academic achievement to deteriorate (Besharat et al., 2011).

This issue sometimes makes the condition of adolescent personality formed from parenting seen from the problems experienced by the adolescents both at school and at home. The Central Statistics Agency (BPS), Bappenas and UNFPA conducted research on adolescents in 2010 and found that some 63 million adolescents aged 10 to 24 years in Indonesia were vulnerable to unhealthy behaviour. Freud defines anxiety as an unpleasant feeling, followed by specific physiological reactions such as heart rate changes and breathing. According to Freud, anxiety involves perceptions about uncomfortable feelings and physiological responses. In other words, anxiety is a reaction to a situation that is considered dangerous (Compton, 1972). Anxiety, in the Islamic view, is the condition of an individual, among others. The type of conditions include the narrowness of the soul (Surah Al Hijr: 97-99), fear (Surah Al Ahzab: 19), anxiety (QS Al Maarij: 20), lamentation (Surah Al Naziat: 19-22), excessive fear (Surah Al Ahzab: 26), panic (Surah Al Anbiya: 103), confusion (Surah Al-Hajj: 1) -2), losing minds (QS. Al-Hajj: 2).

Several factors can cause individuals to experience anxiety. These factors are biological conditions, the ability to adapt/defend themselves to the environment obtained from development and experience, as well as adaptation to stimuli, situations, or stressors. Sources of stressors/situations that can cause anxiety come from the social environment. The social environment has rules, 
habits, laws that apply in certain areas. These factors cause individuals to adjust to the existing social environment. The character or personality possessed by students is inseparable from the parenting process carried out by parents at home and the influence of the social environment or referred to as Biosocial. Biosocial is a psychological approach that seeks to understand social behaviour by connecting with physiological symptoms (Pincus \& Krueger, 2015). According to the biosocial approach in Millon's personality typology, there are several types of personality. They are

1. Passive Independent: Narcissistic Personality

2. Active Independent: Antisocial Personality

3. Passive Dependents: Submissive Personality

4. Active Dependents: Histrionic Personality

5. Passive Ambivalent: Obsessive-Compulsive Personality (conforming)

6. Active Ambivalent: Passive-Aggressive Personality (negativistic)

7. Detached Passive: Schizoid Personality (Asocial)

8. Detached Active: Avoidant Personality

The eight typologies of Millon's personality are also in the DSM V (Diagnostic Statistic Manual) published by APA (American Psychological Association).

\section{B. Personality Shaping Factors}

Factors that affect personality include physical, intelligence, gender, peers, family, culture, environment, and social culture, as well as internal factors such as emotional distress. Internal factors that include biological and hereditary factors, genetic or innate elements from birth belong to hereditary influences of one of the traits or a combination of both parents. Emotional pressure is a factor that affects the personality, (Setiawan et al., 2019), and one of them is an internal factor from within an individual, such as emotional distress.

Adolescence is a time of emotional turmoil that is famous for emotional changes. JB. Watson states that humans have three primary emotions. One of them is fear, which in later developments can become anxiety (Beck et al., 2009). Adjustment to other types includes one of the factors that cause stress in adolescents. After adolescence, each nature inclines to get along with different models that require adaptation and cause tension. The treatment of stiff parents can also cause teens to feel depressed and bound or feel underestimated. It might even cause conflict with family members. This situation can cause anxiety and discomfort in adolescents.

In the school environment, some conditions cause pain, which is a failure to take lessons. There is a feeling of fear that their friends will not accept them, so this will cause discomfort, despair, and anxiety, unreasonable feelings that are unavoidable, accompanied by feelings of helplessness and inability to solve the problems. Meanwhile, the external factor starts with the family. A family is the primary determinant of the formation of a child's personality. The treatment of loving parents and the education of life values, both religious values and 
socio-cultural values given to children are contributory factors to prepare children to become healthy individuals.

\section{METHOD}

This research is included in experimental research. The research subjects in this study used a purposive sampling technique. Subjects were not chosen randomly but instead were selected from the following specific criteria. This approach includes nonprobability sampling because it does not aim to generalize research findings, these criteria are junior high school students from grades 1 to grade 3 who have adolescents, aged 12 to 17 years, have problems at school in the form of juvenile delinquency so that they get several letters calls to their parents because of their distorted behaviour at school.

The sample came from 2 SMPIT schools, where the first school as an experimental group that would get patient training was called SMPIT X, while the secondary school was a control group that did not get the training called SMPIT Y. The number of samples from the experimental and control groups had a total of 16 students each. The research method used is Quasi-Experimental, an experimental design that is used because ethically and practically, this research is limited or cannot be applied to everyone randomly, and is often seen as pseudo or not real experiments. A quasiexperimental design is research approaching a real analysis where it is impossible to control/manipulate all relevant variables. One of the experimental design studies that are very widely used in the validation study of intervention modules is the Pretest-Posttest Control Group Design.

This study uses two groups of subjects, so the experimental design used is twogroup design, Pretest-Posttest Control Group Design, or Untreated Control Group Design with Dependent Pretest and Posttest Samples it is a quasi-experimental form where the results are obtained by comparing experimental groups and unequal control groups. The different values of the two groups are then compared to determine whether there are significant differences. The design of this study is, as shown in Figure 3.

\begin{tabular}{llrr} 
NR & O1 & X & O2 \\
\hdashline NR & O1 & & O2
\end{tabular}

Figure 3.

Design Eksperimen Untreated Control Group Design with Dependent Pretest and Posttest Samples

Keterangan:

$$
\begin{array}{ll}
\mathrm{NR} & =\text { Non-Randomized } \\
\mathrm{O} 1 & =\text { pretest } \text { Patience Exercise } \\
---- & =\text { comparison } \\
\mathrm{X} & =\text { treatment of training } \\
\mathrm{O} 2 & =\text { postest Patience Exercise }
\end{array}
$$




\section{RESULT AND DISCUSSION}

The researcher conducted observations at Medan X Integrated Islamic Middle School, where the school has a specific curriculum in the Department of Religion and also the Ministry of National Education. The application of Patience Therapy that uses Islamic religious values will have a smooth implementation. Integrated Islamic Middle School X Medan is a school that seeks to develop children's intellectual and personality while still making the message of Islam as an inspiration so that children have intelligent minds, noble morals, right creeds, and pleasant activities.

This school is an effort to develop Islamic education integrated with general science education, as well as a forum that forms high-achieving and noble Muslim students. As a comparison, the researchers also observed the young Muslim activists in the district area, not so far from the city of Medan. The researcher chose the young Muslim activists because their activities, using the Islamic ethical approach and the education level of the young Muslim activists, were the junior level. The vision of the Integrated Islamic Middle School X Medan is to form high achieving students with moral values. The vision is in the mission of Medan X Islamic Middle School, which is to educate and equip children with Intellectual, Social-Emotional, and Spiritual abilities.

Nevertheless, the Integrated Islamic Middle School learning objectives created high achievement and students' moral well. However, there were times when these goals were out of reach due to the obstacles experienced by students. To overcome the learning problems encountered by students in the Integrated Islamic Middle School, the expectations of the Vision and Mission of the school can be more helpful in the formation of proper student behaviour. However, in reality, there were still many students who had learning difficulties, so they showed bad behaviour that was not in line with the vision's expectations and the mission. This issue is what underlined why the researcher observed the school.

As for the students' behaviour at SMPIT X Medan, they tended to challenge the teacher and did not want to complete the assignment. They also ditched, disturbed, and even made noises in the classroom situation noisy when there was a lesson. With the complaints experienced by students and low results of learning achievement in schools, some students were shy and quiet changed their behaviour. Unfortunately, it disrupted teaching and learning activities in the classroom.

The subjects in this study were nine students of SMPIT X Medan who had specific criteria. They were troublemakers at school where their parents had to come to the school several times due to their deviant behaviour at school, whereas 16 students were young Muslim activists used as a comparison. Still, they had differences with the experimental group investigated. In contrast, the sample group of mosque youths only had the criteria of having anxiety and being at the school level in junior high school without having to have school problems. 
Some students of SMPIT X Medan said that they experienced anxiety, nervousness, painful head, substantial neck, hands or limbs trembling, insomnia, excessive sweat, difficulty speaking or breathing, strong heartbeat, extreme caution. When viewed from the perspective of the DSM (Diagnostic Statistics Manual) issued by the APA (American Psychological Association), those characteristics belong to characteristics of anxiety (Nevid, 2005). To deal with pressures and burdens in the form of hopes and desires from these parents requires patience from within the students because, without high tolerance, there will be a variety of unexpected behaviours. As for the student who will experience differences of appreciation about his mental state where the problem sometimes makes students experience anxiety and ultimately lead to stress.

The above conditions trigger conflict and frustration for students. In this case, the students experienced a change in behaviour from cheerful to shy. Even some quiet students turned into troublemakers in class. Conflict and frustration are conditions that can make students experience stress even though the way they deal with them is different caused by differences in views on the situation faced. One effort that can change the behaviour and mindset of students who are irrational into more rational thoughts and beliefs is through a religious approach for students through Islamic Psychotherapy, Patience Therapy.

Islamic psychotherapy is an effort to overcome some psychiatric problems based on Islamic religious views. Islamic psychotherapy believes that faith and closeness to religion will be a significant force for good in solving one's mental issues. Preventing various psychiatric problems and perfecting human qualities besides the psychospiritual approach (with faith and closeness to God). Islamic psychotherapy also has a base on the use of thinking tools and real human efforts to improve themselves. Islamic psychotherapy does not merely free people from illness but also enhances the quality of one's psyche.

A wrong understanding and experience of religion can cause conflict and anxiety in a person. Conversely, understanding, and experiencing true religion can resolve disputes and anxiety so that cognitive therapy in Islam can help someone think, process, and evaluate problems to calm down and reduce inner tension (William Hart, 2020). Several studies have found that a form of religious psychotherapy can be useful for Muslim clients who suffer from anxiety, depression, and feelings of loss. Ideas that originate from Islam will identify and modify irrational beliefs. They are a combination of Cognitive therapy and religious therapy, namely the use of religious themes. In treating patients who experience anxiety and depression through religious psychotherapy, Razali et al. (2002) identified negative thoughts in patients and modified them by using cognitive techniques directed by the Qur'an and hadith. They also discussed religious issues and cultural beliefs related to illness and gave lifestyle advice so that they could change following the Prophet Muhammad's habits. In this study, students of SMPIT $X$ received cognitive psychotherapy in Islamic Psychotherapy in the form of patience therapy. To deal with pressures and burdens in the form of hopes and desires from these parents 
requires patience (Olivern, 2008) from within the students because, without high tolerance, there will be a variety of unexpected behaviours. Thus, Islamic cognitive psychotherapy is the provision of patience therapy by improving students' perspectives from the Islamic approach, according to Qur'an and Hadith, to the students' problems at SMPIT X.

There, the students experienced changes in thoughts, habits, and behaviours that were previously incorrect (irrational). The students got wrong ideas about themselves, other people, life, and various problems. They could change behaviours with the hope of being able to ease their anxiety by integrating Islamic values. Parenting style, according to Spera (2005), is an emotional climate in which parents raise their children. Parenting styles are behavioural patterns that are used by primary caregivers to interact with their children. These parenting patterns then create an emotional climate expressed by the behaviour of their parents. There are several parenting styles done by parents to their children, according to Baumrind (Dehyadegary et al., 2012), namely authoritative who are demanding and responsive, authoritarian who are demanding but not sensitive, and permissive who are responsive but not demanding. Each type of parenting has a different effect on the child's mental appreciation, which can lead to anxiety and emotions.

The measuring instrument used was a measure constructed by the researcher based on the anxiety characteristics of the DSM consisting of 103 items and patience from Subandi (2011) and Umar Yusuf (2010) composed of 60 questions. The results of data processing obtained results for anxiety, namely for the experimental group, the value of $Z=-1,362^{\mathrm{a}}$ with $p=0,173$. Since $p 0.173>0.05$, H0 was accepted, and H1 was rejected. This result means that there was a decrease in not so significant anxiety symptoms after a pretest and posttest in the experimental group. For the control group, the value of $Z=-0.440^{a}$ was $p=0.660$. Since $p 0.660>0.05$, H0 was accepted, and $\mathrm{H} 1$ was rejected. This result means that there was a decrease in not so significant anxiety symptoms before (pretest) and after (posttest) in the control group.

The results of data processing obtained results for patience, which was for the experimental group, the value of $Z=-2.666^{\mathrm{a}}$ with $p=0.008$. Since $p 0.008<0.05$, then $\mathrm{H} 0$ was rejected, and $\mathrm{H} 1$ was accepted. This result means that there was a significant increase in patience after being given a pretest and posttest in the experimental group. For the control group, the value of $Z=-1.629^{a}$ was $p=0.103$. Since $p 0.103>$ 0.05 , H0 was accepted, and $\mathrm{H} 1$ was rejected. This result means that there was no significant increase in patience before (pretest) and after (posttest) in the control group.

Meanwhile, the intervening variables in this study were personality and parenting. The results of the analysis of the personality types of students through PBQ (Personality Belief Questionnaire) were SMPIT Nurul Azizi (Anti-social 44.44\%, Passive Aggressive 22.22\%, Narcissistic $11.11 \%$, Compulsive $11.11 \%$, and Borderline $11.11 \% \%$ ) and Mosque Youth (Anti-social 56.25\%, Narcissistic 18.75\%, Paranoid $12.5 \%$, Histrionic $6.25 \%$ and Compulsive $16.25 \%$ ). The second Intervening Variable 
is parenting. This study had a base on the theory of parenting from Baumrind. He mentions that there are three types of parenting parents, namely democracy, authoritarianism, and permissiveness. Analysis of the parenting experienced by students of SMPIT Nurul Azizi and young Muslim activists through interviews showed that almost all teenagers were raised with authoritarian parenting from parents and grandparents who took part in raising them.

\section{CONCLUSIONS}

The treatment given affected the degree of anxiety because before and after treatment showed different degrees of anxiety and an increase in the level of patience. The results of the analysis concluded that students living by different parents' parenting style formed a particular personality type. Parents with authoritarian and permissive types would develop the Anti-Social Personality type, following Millon's typology theory of the Independent Active (Anti-social) Type. Conceptually, patience can be interpreted as a person's ability to manage, control, direct, and overcome various needs/problems or difficulties that are faced comprehensively and integratively.

In patience, there is steadfast, diligent, and steadfast in dealing with various problems that can overcome them properly. The definition of patience based on research includes self-control, which is holding back emotions and desires, thinking long, and forgiving mistakes (Sudirman, et, al. 2019), tolerance towards procrastination. Fortitude is to survive in a difficult situation by not complaining. Persistence involves being tenacious, working hard to achieve goals, and finding solutions to problems. Next, this behaviour also accepts the bitter truth with sincerity and gratitude as well as being calm, not in a hurry.

Referencing some definitions of patience from research conducted by Umar (2014) and, several concepts of patience follow the idea of psychology in general, namely the Concept of Fortitude and Firm. Fortitude here means to stand to suffer, feel the bitterness of life without complaining, persist in overcoming difficulties, and survive in stressful situations. The concept of Psychology that is close to this theme is the concept of Adversity Quotient (AQ). Although the idea of AQ is widespread, the similarity is close to the concept of patience in the theme of fortitude. Another idea is resilience and hardness personality. Resilience is the ability to adapt, coping, confront difficulties, and rise again from stressful situations (adversity).

\section{REFERENCES}

Al-Abrasy, A. (1970). Dasar-dasar Pokok Pendidikan Islam, Terjemah Bustami A Gana dan Jahar Bahri. Bulan Bintang.

Beck, H. P., Levinson, S., \& Irons, G. (2009). Finding little Albert: A journey to John B. Watson's infant laboratory. American Psychologist, 64(7), 605-614. https://doi.org/10.1037/a0017234 
Besharat, M. A., Azizi, K., \& Poursharifi, H. (2011). The relationship between parenting styles and children's academic achievement in a sample of Iranian families. Procedia - Social and Behavioural Sciences, 15, 1280-1283. https:/ / doi.org/10.1016/j.sbspro.2011.03.277

Chaer, Moh. T., Wasim, A. T., \& Khilmiyah, A. (2019). Children's Education in The Story of Single Mothers in Qur'ân. International Journal of Education and Learning, 1(2), 63-72. https:// doi.org/10.31763/ijele.v1i2.36

Chaer, M. T., \& Suud, F. M. (2020). Pendidikan Anak Perspektif Hamka (Kajian Q.S. Luqman/31: 12 -19 Dalam Tafsir Al-Azhar). 02, 15.

Chaplin, C. (1993). Kamus Lengkap Psikologi, alih bahasa Kartifni Kartono. PT. Grafindo.

Compton, A. (1972). A Study of the Psychoanalytic Theory of Anxiety. I. The Development of Freud's Theory of Anxiety. Journal of the American Psychoanalytic Association, 20(1), 3-44. https:/ / doi.org/10.1177/000306517202000101

Dehyadegary, E., Yaacob, S., Rumaya, J., \& Abu Talib, M. (2011). Relationship between Parenting Style and Academic Achievement among Iranian Adolescents in Sirjan. Asian Social Science, 8. https:/ / doi.org/10.5539/ass.v8n1p156

Dobre, C., Rădulescu, D., Gabor, S., Gherasim, A. M., \& Vas, R. (2014). Parenting style and child anxiety. 13.

Hamami, T., Suud, F. M., \& Rahmatullah, A. S. (2019). Al-Islam dan kemuhammadiyahan sebagai basis pendidikan karakter. 21.

Hurlock, B. E. (2000). Psikologi Perkembangan-Suatu Pendekatan Sepanjang Rentang Kehidupan, Edisi Kelima. Erlangga.

Konstantinos V. Petrides. (2019). A conceptual application of Psychobionomy to the field of personality and individual differences, Personality and Individual Differences, 147, 135-143, https://doi.org/10.1016/j.paid.2019.04.018.

Oliver S. Curry, Michael E. Price, Jade G. Price. 2008. Patience is a virtue: Cooperative people have lower discount rates, Personality and Individual Differences, 44 (3), 780-785, https:/ / doi.org/10.1016/j.paid.2007.09.023.

Nevid, J. S. (2005). Psikologi Abnormal (5th, Jilid 1 ed.). Erlangga.

Nikoogoftar, M., \& Seghatoleslam, S. (2015). The Role of Parenting Styles in Predicting Adolescent Behavioural and Emotional Problems. PCP, 3(1), 2330.

Papalia, O., \& Feldman. (2009). Human Development-Perkembangan Manusia (Edisi 10, Buku 2). Salemba Humanika.

Pincus, A. L., \& Krueger, R. F. (2015). Theodore Millon's Contributions to Conceptualizing Personality Disorders. Journal of Personality Assessment, 97(6), 537-540. https:// doi.org/10.1080/00223891.2015.1031376

Razali, S., Aminah, K., \& Khan, U. (2002). Religious-Cultural Psychotherapy in the Management of Anxiety Patients. Transcultural Psychiatry - TRANSCULT PSYCHIATRY, 39, 130-136. https:/ / doi.org/10.1177/136346150203900106

Santrock, J., W. (2002). Life Span Development-Perkembangan Masa Hidup. Terj. Erlangga. 
Setiawan, W. (2018). Reward and Punishment dalam Perspektif Pendidikan Islam. AL-MURABBI: Jurnal Kependidikan dan Keislaman, 18.

Setiawan, W., Tajab, M., \& Chaer, M. (2019). Ruh, Soul, Heart, Mind, and Body in the Perspective of Islamic Educational Psychology. Proceedings of the Proceedings of 1st Workshop on Environmental Science, Society, and Technology, WESTECH 2018, December 8th, 2018, Medan, Indonesia. Proceedings of 1st Workshop on Environmental Science, Society, and Technology, WESTECH 2018, December 8th, 2018, Medan, Indonesia, Indonesia. https:/ / doi.org/10.4108/eai.8-12-2018.2283959

Sudirman, S. A., Suud, F. M., Rouzi, K. S., \& Sari, D. P. (2019). Forgiveness and Happiness through Resilience. Al-Qalb: Jurnal Psikologi Islam, 10(2), 113-132.

Spera, C. (2005). A Review of The Relationship Among Parenting Practices, Parenting Styles, And Adolescent School Achievement. Educational Psychology Review, 17(2).

Subandi. (2011). Sabar: Sebuah Konsep Psikologi. Jurnal Psikologi, 38(2), 215.

Umar, Y. (2014). Prosiding SNaPP2014 Sosial, Ekonomi, dan Humaniora.

Vardia, M. A., \& Nurdibyanandaru, D. (2018). Pengaruh Pola Asuh (Authoritative, Authoritarian, Permissive, dan Negligent) dan Adversity Quotient Terhadap Motivasi Berprestasi Pada Siswa SMA Taman Siswa Malang. Jurnal Psikologi dan Perkembangan, 7, 21.

William Hart, Kyle Richardson, Christopher J. Breeden. (2020). Profiling HEXACO factors on self-presentation tactic use, Personality and Individual Differences, 153, https://doi.org/10.1016/i.paid.2019.109649. 